\title{
Intra- and Intergeneric Similarities of the rRNA Cistrons of Alteromonas, Marinomonas (gen. nov.) and Some Other Gram-negative Bacteria
}

\author{
By A. VAN LANDSCHOOT AND J. DE LEY* \\ Laboratorium voor Microbiologie en microbiële Genetica, Rijksuniversiteit, Ledeganckstraat 35 , \\ B-9000 Gent, Belgium
}

(Received 6 December 1982; revised 28 March 1983)

\begin{abstract}
${ }^{14} \mathrm{C}$-labelled rRNA was prepared from Alteromonas macleodii ATCC 27126 and from Alteromonas haloplanktis ATCC $14393 .{ }^{3} \mathrm{H}$-labelled rRNA was isolated from Alteromonas vaga ATCC 27119 and Alteromonas putrefaciens ATCC 8071 colony type t1. These rRNAs were hybridized under stringent conditions with filter-fixed DNA from various Alteromonas strains and from organisms of marine origin and/or with $\mathrm{mol} \% \mathrm{G}+\mathrm{C}$ values in the range 40 to 50 . Each hybrid was described by its $T_{m(e)}$ and percentage of rRNA binding. From rRNA similarity maps and $T_{m(e)}$ dendrograms the following conclusions were drawn. The genus Alteromonas is very heterogeneous and consists of four rRNA branches: (1) Alt. macleodii alone; (2) the Alt. haloplanktis cluster, containing most of the named Alteromonas species and a number of organisms which should be renamed Alteromonas ('Pseudomonas marinoglutinosa', 'Pseudomonas nigrifaciens', 'Pseudomonas atlantica' ATCC 19262, 'Pseudomonas carrageenovora', 'Pseudomonas piscicida', and several unnamed alginolytic bacteria); we propose to limit the genus Alteromonas to the former two clusters; (3) Alt. putrefaciens, the rRNA cistrons of which resemble those of the Vibrionaceae and are as different from the above two Alteromonas rRNA branches as are those of the Vibrionaceae, the Enterobacteriaceae and Aeromonas; 'Pseudomonas rubescens' belongs to this branch and Alteromonas hanedai seems to be a remote relative; (4) Alteromonas communis and Alt. vaga constitute another, separate rRNA branch; in conjunction with their special phenotypic features, we propose to create a new genus, Marinomonas, for them. The exact taxonomic position of 'Alteromonas thalassomethanolica' could not be established.
\end{abstract}

\section{INTRODUCTION}

Baumann et al. (1972) created the genus Alteromonas for a group of Gram-negative, aerobic, polarly flagellated, heterotrophic marine bacteria. The main difference from Pseudomonas was the range of the mean molar percentage of $\mathrm{G}+\mathrm{C}(\mathrm{mol} \% \mathrm{G}+\mathrm{C})$ of the DNA, extending from 40 to 50 for Alteromonas. They described four species: Alteromonas vaga, Alteromonas communis, Alteromonas macleodii (type species of the genus), and 'Alteromonas marinopraesens' [subsequently changed by Reichelt \& Baumann (1973) to Alteromonas haloplanktis]. Several additional species have since been proposed: Alteromonas luteoviolacea (Gauthier, 1976a, 1982), Alteromonas rubra (Gauthier, 1976b) and Alteromonas citrea (Gauthier, 1977), Alteromonas espejiana and Alteromonas undina (Chan et al., 1978), Alteromonas aurantia (Gauthier \& Breittmayer, 1979), Alteromonas hanedai (Jensen et al., 1980), and 'Alteromonas thalassomethanolica' (Yamamoto et al., 1980). Taxon names in quotation marks are not in the Approved Lists of Bacterial Names (Skerman et al., 1980) nor on the validation lists, and have not been published since 1 January 1980 in the International Journal of Systematic Bacteriology.

'Pseudomonas' putrefaciens has been regarded as a very important organism in the spoilage of chilled protein. It has been isolated from fish, butter, oil brine and human clinical specimens. It has been associated with infections (Debois et al., 1975). 'Pseudomonas rubescens' has been isolated from cutting oil (Pivnick, 1955). Lee et al. (1977) proposed to rename both species as 
Alteromonas putrefaciens (Anonymous, 1981). The $\mathrm{mol} \% \mathrm{G}+\mathrm{C}$ values of the latter organisms fall within the range of Alteromonas. The genetic structure of Alt. putrefaciens was studied by Owen et al. (1978) who found some correlation between four DNA homology groups and their sources of isolation.

DNA/rRNA hybridizations are a powerful tool to reveal genetic homogeneity or heterogeneity in a named genus or family, and the establishment of relationships between genera (De Ley et al., 1978; De Smedt et al., 1980; De Smedt \& De Ley, 1977; Gillis \& De Ley, 1980; De Vos \& De Ley, 1983). We have examined the degree of heterogeneity within Alteromonas, the eventual validity of this genus, and its taxonomic neighbours by this technique. We also examined a number of other organisms of marine origin and/or with low $\mathrm{mol} \% \mathrm{G}+\mathrm{C}$ values, which might eventually be related to the present alteromonads. These included some Pseudomonas organisms which are not on the Approved Lists and whose taxonomic status is still uncertain, and some unnamed alginolytic bacteria isolated by Mrs S. Meland from northern Norway. The purified DNA from all these organisms was hybridized with labelled rRNA from selected Alteromonas strains. A number of taxonomically well-located strains were included as controls.

\section{METHODS}

Bacterial strains and growth media. Table 1 lists the bacterial strains used and their corresponding growth media. The purity of the strains was checked by plating and by microscopic examination of living and Gram-stained cells. Four Alteromonas strains and three Pseudomonas strains showed two or three colony types on plates. The different types are indicated in the text by $\mathrm{t} 1, \mathrm{t} 2$ and $\mathrm{t} 3$. The compositions of the growth media are given in De Smedt \& De Ley (1977), Gillis \& De Ley (1980) and De Vos \& De Ley (1983). The compositions of additional growth media are summarized in Table 2.

Mass cultures for the extraction of DNA were grown as described by De Smedt \& De Ley (1977). Cells were harvested in $0.01 \mathrm{M}$-phosphate buffer $\mathrm{pH} \mathrm{7,} \mathrm{containing} \mathrm{the} \mathrm{same} \mathrm{percentage} \mathrm{of} \mathrm{NaCl}$ as in the medium used for growth. In some cases, to prevent lysis of the cells, it was necessary to harvest and wash the cells using a solution with the same ionic composition as the growth medium.

Extraction of DNA and fixation of the single-stranded DNA on membrane filters. The procedures of Gillis \& De Ley (1980) were used.

Chemical determination of DNA fixed on filters. Early in the work the method of Burton (1956) was used, as described by De Smedt \& De Ley (1977); later, a modified method was used (Richards, 1974) involving a more stable solution of $2.25 \%(\mathrm{w} / \mathrm{v})$ diphenylamine and $0.005 \%(\mathrm{w} / \mathrm{v})$ paraldehyde instead of $1.5 \%(\mathrm{w} / \mathrm{v})$ diphenylamine and $0.005 \%(\mathrm{w} / \mathrm{v})$ acetaldehyde.

Preparation of labelled $r$ RNA. $\left[{ }^{14} \mathrm{C}\right] \mathrm{rRNA}$ was prepared from the type strains of Alt. macleodii ATCC 27126 and Alt haloplanktis ATCC 14393. $\left[{ }^{3} \mathrm{H}\right] \mathrm{rRNA}$ was prepared from the type strain of Alt. vaga ATCC 27119 and Alt. putrefaciens ATCC 8071. The latter strain gave two colony types: $t 1$ gave larger, more shiny and yellow colonies than $\mathbf{t}$. Microscopically the cells were the same and their DNAs had an identical mol $\% \mathrm{G}+\mathrm{C}$ of $45 \cdot 5$. The electrophoretic protein patterns of both types were very similar and DNA/DNA reassociation revealed that $t 1$ was $100 \%$ related to $t 2$. Colony type $t 1$ was used for the preparation of $\left[{ }^{3} \mathrm{H}\right] \mathrm{rRNA}$.

The growth medium for the preparation of rRNA from Alt. putrefaciens ATCC $8071 \mathrm{t} 1$ was Z25 whereas Z24 (Table 2) was used for the preparation of labelled rRNA from all other type strains. The preparation of labelled rRNAs was as described by De Ley \& De Smedt (1975), except that the rRNA solutions contained $0 \cdot 2 \%(w / v)$ bentonite during the whole procedure (Midgley, 1965).

Saturation hybridization between labelled $r R N A$ and filter-fixed DNA: thermal stability of the DNA/rRNA hybrids. The method was described by De Smedt \& De Ley (1977). Two parameters were measured: (1), $T_{m(e)}$, which is the temperature at which $50 \%$ of the hybrid is denatured; (2) the percentage of rRNA binding, which represents the amount of labelled rRNA duplexed, in $\mu \mathrm{g}$ per $100 \mu \mathrm{g}$ DNA fixed on the filter, after ribonuclease treatment. Both parameters are derived from the melting curves of the hybrids.

\section{RESULTS}

$16 S$ and $23 S$ fractions

In Fig. 1 the distribution of the labelled rRNA in sucrose gradients is shown. The $23 \mathrm{~S}$ $\left[{ }^{14} \mathrm{C}\right] \mathrm{R}$ NA fraction of Alt. macleodii ATCC 27126 was used for DNA/rRNA hybridizations. There is no evidence that the $23 \mathrm{~S}$ fraction was contaminated by the $16 \mathrm{~S}$ fraction. The specific activity [c.p.m. ( $\mu \mathrm{g}$ rRNA) $\left.{ }^{-1}\right]$ of this rRNA was 5800 . The $16 \mathrm{~S}$ fraction of $\left[{ }^{14} \mathrm{C}\right] \mathrm{rRNA}$ from $A l t$. 


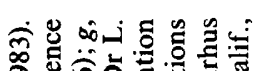

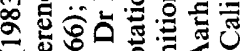

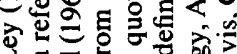

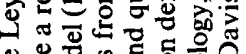
ดั 흘 \&

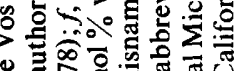

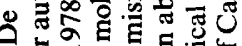

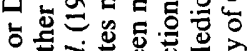
ठิ \&

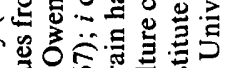

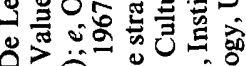

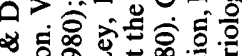

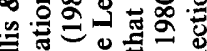

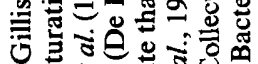

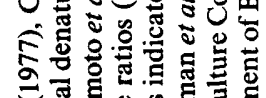

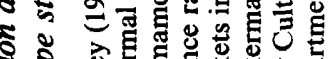

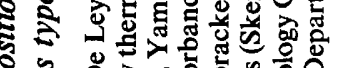

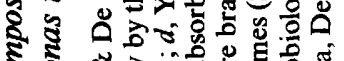

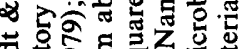

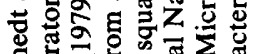
को 픈. ङ. ธี

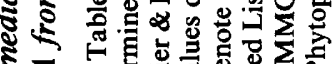

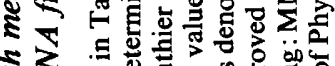
引

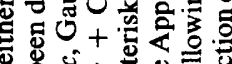

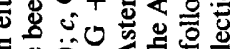

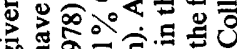
कम

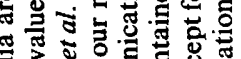

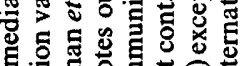

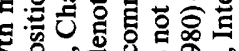
0.00

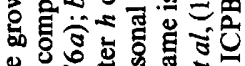

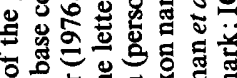
은.

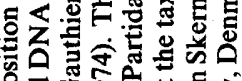

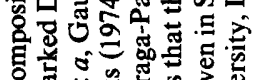

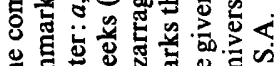

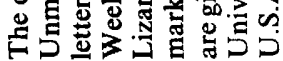

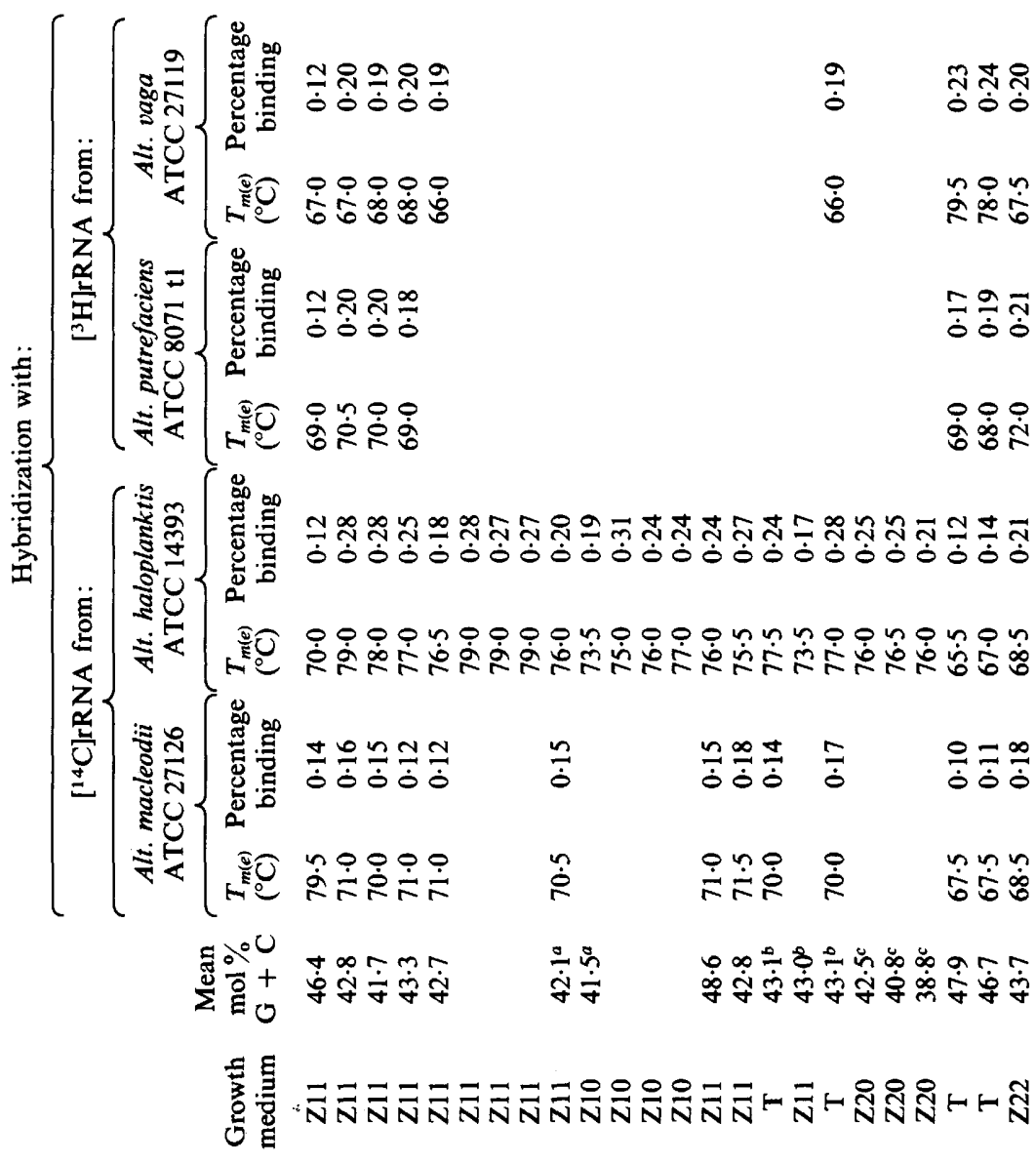

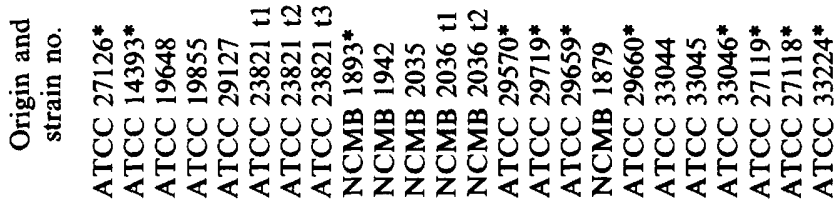

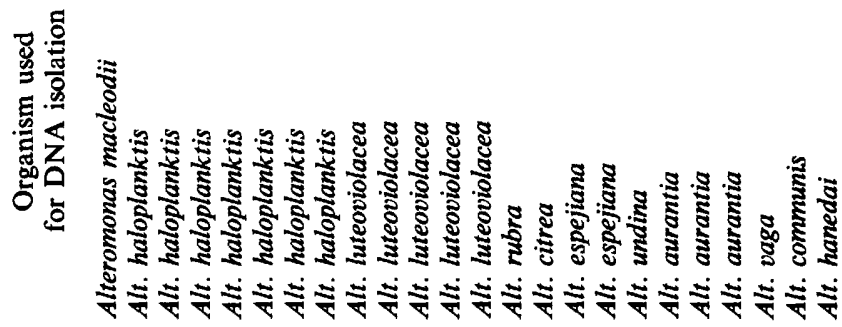

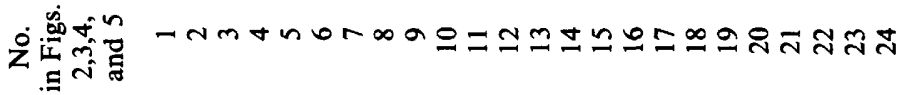




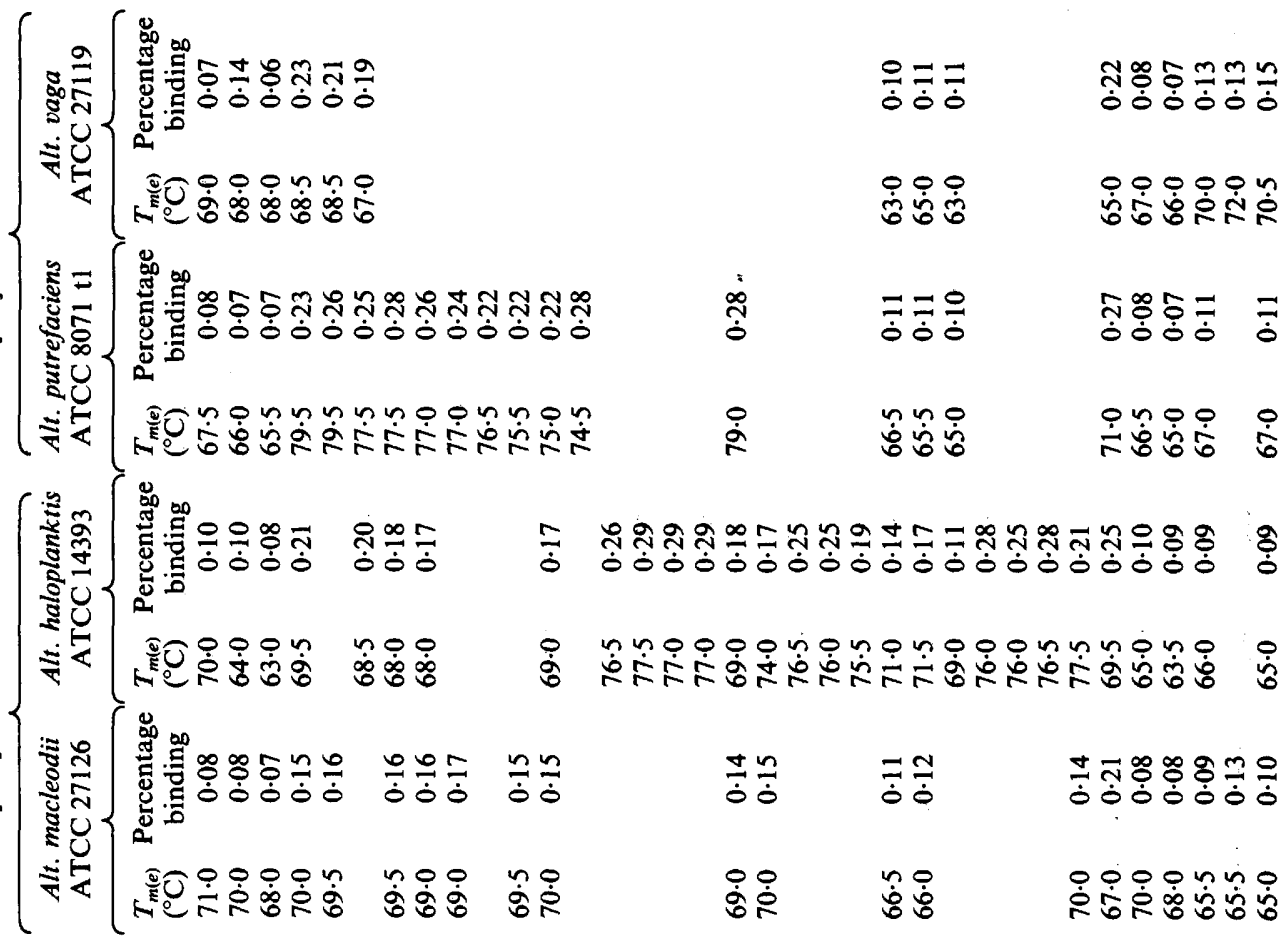

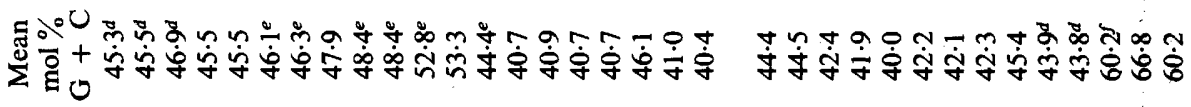

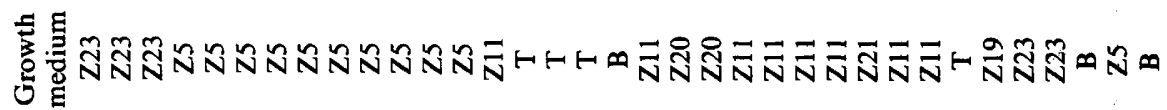

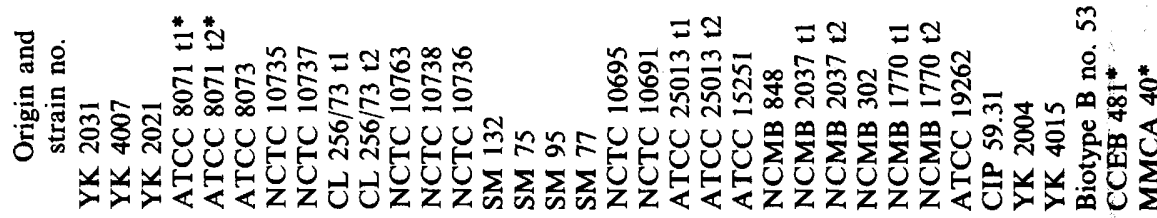

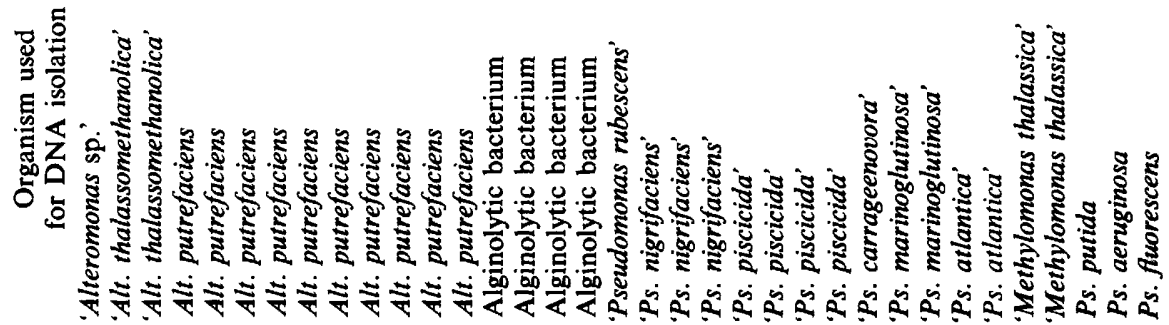

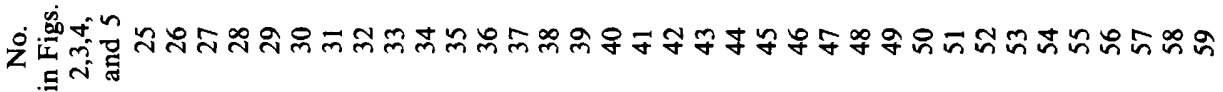




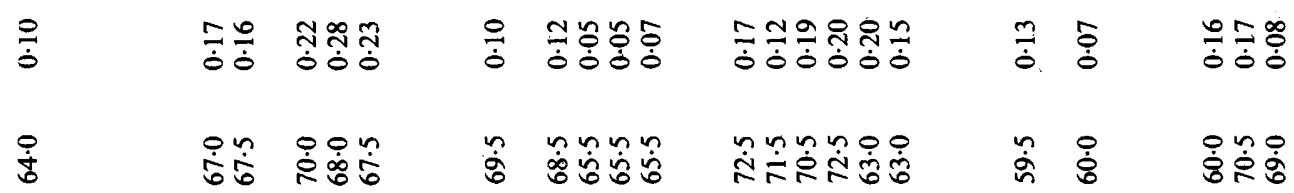

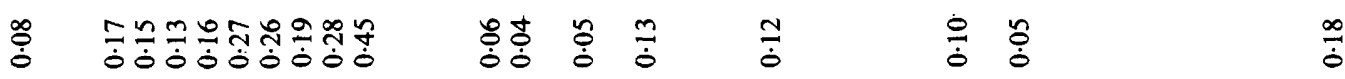

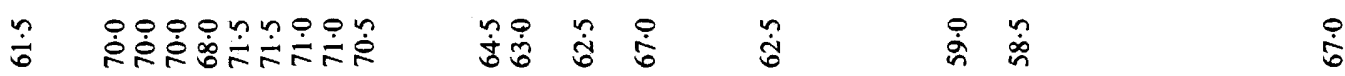

\& $\quad$ தे

紡

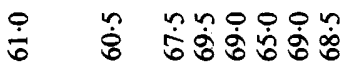

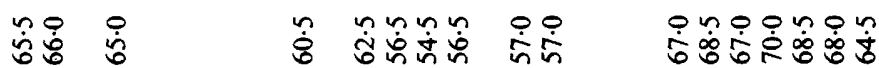

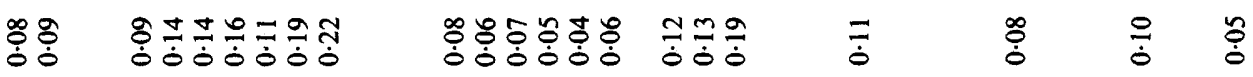

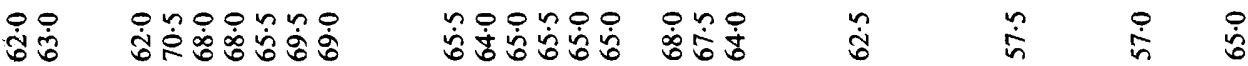

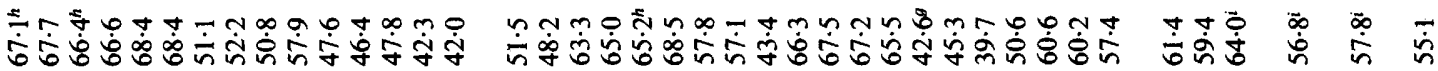

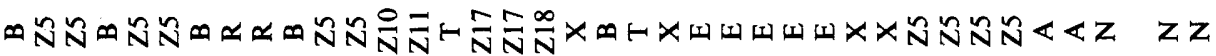

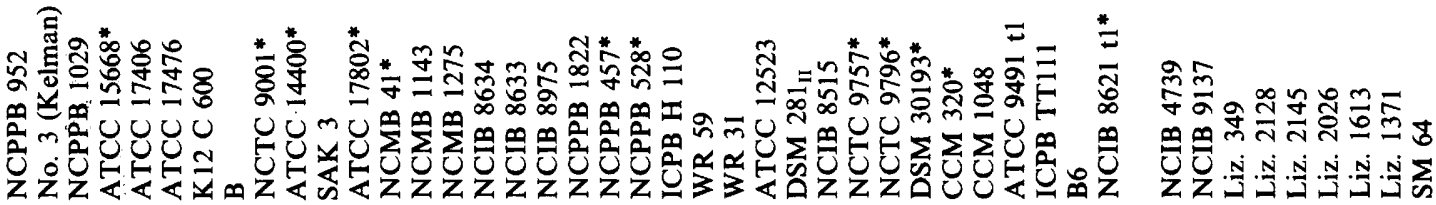

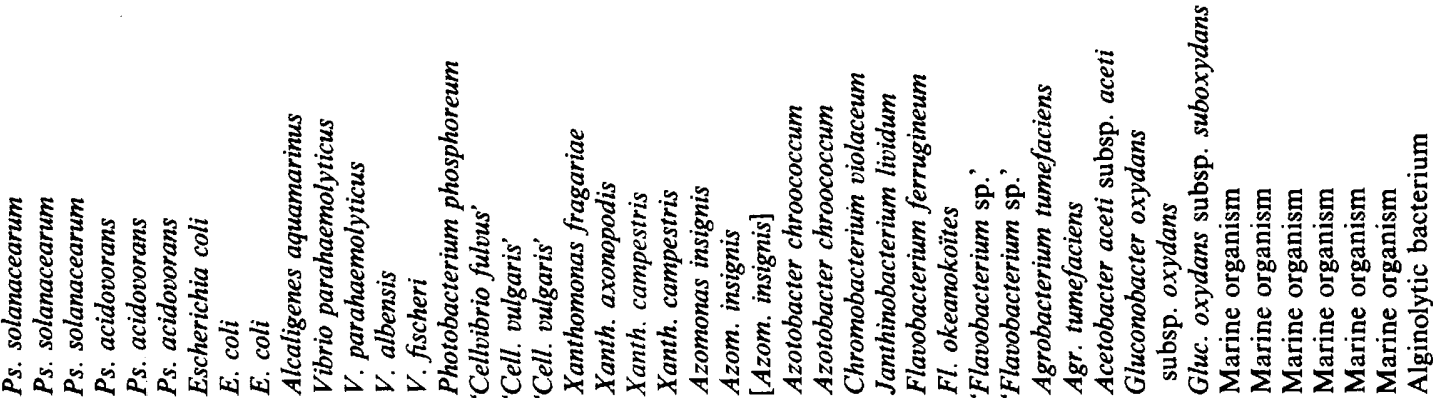

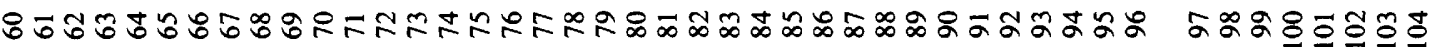


Table 2. Composition $(\%, w / v)$ of growth media

\begin{tabular}{|c|c|c|c|c|c|c|c|c|c|}
\hline Component Medium & $\mathrm{Z} 17$ & $\mathrm{Z} 18$ & Z19 & $\mathrm{Z} 20$ & $\mathrm{Z} 21$ & $\mathrm{Z} 22$ & $\mathrm{Z} 23$ & Z24 & $\mathbf{Z 2 5}$ \\
\hline Glucose & & & & & & 0.2 & & 0.6 & 0.6 \\
\hline Lactose & & 1 & & & & & & & \\
\hline Methanol & & & & & & & 1 & & \\
\hline Starch & 1 & & & & & & & & \\
\hline Yeast extract & & & & 0.1 & $0 \cdot 3$ & & & 0.5 & 0.5 \\
\hline Meat extract & 1 & 1 & & & & & & & \\
\hline Peptone & 1 & 1 & & 0.5 & 0.5 & & & & \\
\hline Proteose peptone & & & & & & 1 & & & \\
\hline Calf brain infusion & & & & & & 1.25 & & & \\
\hline Beef heart infusion & & & & & & 0.5 & & & \\
\hline Casamino acids & & & 0.1 & & & & & & \\
\hline Vitamin $\mathbf{B}_{12}$ & & & & & & & $10^{-7}$ & & \\
\hline$\left(\mathrm{NH}_{4}\right)_{2} \mathrm{SO}_{4}$ & & & & & & & 0.2 & & \\
\hline $\mathrm{KH}_{2} \mathrm{PO}_{4}$ & & & & & & & $0 \cdot 1$ & & 0.27 \\
\hline $\mathrm{K}_{2} \mathrm{HPO}_{4}$ & & & 0.01 & & & & $0 \cdot 2$ & & 0.52 \\
\hline $\mathrm{Na}_{2} \mathrm{HPO}_{4}$ & & & & & & $0 \cdot 25$ & & & \\
\hline $\mathrm{NaCl}$ & 0.5 & 0.5 & $2 \cdot 5$ & & & 0.5 & 2 & 3 & 0.5 \\
\hline $\mathrm{KCl}$ & & & $0 \cdot 1$ & & & & & & \\
\hline $\mathrm{FeSO}_{4} \cdot 7 \mathrm{H}_{2} \mathrm{O}$ & & & 0.002 & & & & $2.8 \times 10^{-5}$ & & \\
\hline $\mathrm{Na}_{2} \mathrm{MoO}_{4} \cdot 2 \mathrm{H}_{2} \mathrm{O}$ & & & & & & & $2.4 \times 10^{-5}$ & & \\
\hline $\mathrm{MnSO}_{4} \cdot \mathrm{H}_{2} \mathrm{O}$ & & & & & & & $8.4 \times 10^{-5}$ & & \\
\hline $\mathrm{MgSO}_{4} .7 \mathrm{H}_{2} \mathrm{O}$ & & & 0.5 & & & & 0.03 & & 0.012 \\
\hline $\mathrm{CaCl}_{2} \cdot 2 \mathrm{H}_{2} \mathrm{O}$ & & & 0.027 & & & & $1.5 \times 10^{-5}$ & & \\
\hline $\mathrm{ZnSO}_{4}$ & & & & & & & $7.8 \times 10^{-5}$ & & \\
\hline $\mathrm{CuSO}_{4} \cdot 5 \mathrm{H}_{2} \mathrm{O}$ & & & & & & & $2.5 \times 10^{-5}$ & & \\
\hline $\mathrm{CoCl}_{2} \cdot 6 \mathrm{H}_{2} \mathrm{O}$ & & & & & & & $2.4 \times 10^{-5}$ & & \\
\hline $\mathrm{Na}_{2}$ EDTA & & & 0.05 & & & & & & \\
\hline Tris & & & 0.4 & & & & & & \\
\hline Tap water* & + & + & & & & & & + & + \\
\hline Distilled water* & & & + & & $25 \%(v / v)$ & + & + & & \\
\hline Artificial seawater* & & & & + & $75 \%(v / v)$ & & & & \\
\hline $\mathrm{pH}$ & $\sim 7$ & $\sim 7$ & $7 \cdot 25$ & $7 \cdot 3$ & $7 \cdot 3$ & $7 \cdot 4$ & 7 & $\sim 7$ & 7 \\
\hline
\end{tabular}

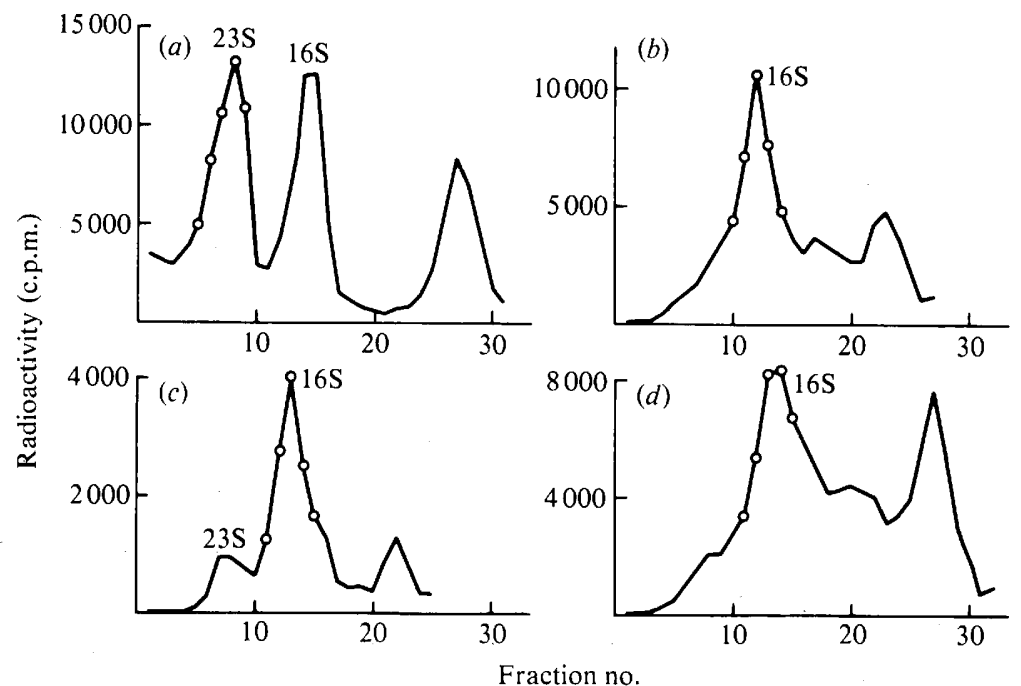

Fig. 1. Distribution of about $1 \mathrm{mg}{ }^{14} \mathrm{C}$-labelled or ${ }^{3} \mathrm{H}$-labelled rRNA in a linear 15 to $30 \%$ sucrose gradient. The procedure was as described in De Ley \& De Smedt (1975). The radioactivity of the fractions was measured after addition of $5 \mathrm{ml}$ scintillation liquid to $10 \mu \mathrm{l}$ of each fraction. The $23 \mathrm{~S}$ or $16 \mathrm{~S}$ fractions, collected for use in DNA/rRNA hybridizations, are marked with open circles. (a) Alt. macleodii ATCC 27126, (b) Alt. vaga ATCC 27119, (c) Alt. haloplanktis ATCC 14393, (d) Alt. putrefaciens ATCC 8071 t1. 
haloplanktis ATCC 14393, $\left[{ }^{3} \mathrm{H}\right] \mathrm{rRNA}$ from Alt. vaga ATCC 27119 and $\left[{ }^{3} \mathrm{H}\right] \mathrm{rRNA}$ of Alt. putrefaciens ATCC 8071 type tl were used. The specific activities of these three rRNAs were 2400,9800 and 10900 c.p.m. ( $\mu$ g rRNA) ${ }^{-1}$, respectively. The $23 \mathrm{~S}$ fraction was either very small or totally lacking from three strains, presumably due to total or partial nicking. The $16 \mathrm{~S}$ peaks may have been contaminated with fragmented 23S fractions, as in Agrobacterium (De Smedt \& De Ley, 1977), but their sedimentation coefficients remained unchanged. It is our experience (Gillis \& De Ley, 1980) that hybridizations with the $23 \mathrm{~S}$ and the $16 \mathrm{~S}$ fractions from the same organism givf similar results, within the limits of reproducibility.

\section{DNA/rRNA hybridizations}

The results of the hybridizations ( $T_{m(e)}$ and percentage of rRNA binding) are compiled in Table 1. For each labelled reference rRNA, the $T_{m(e)}$ values are plotted against the percentage of rRNA binding; the position of each DNA/rRNA hybrid is indicated. The resulting rRNA similarity maps are shown in Figs 2, 3, 4 and 5. It is our experience that taxa outside the rRNA superfamily examined always have about the same location on the similarity maps irrespective of the labelled reference rRNA from the rRNA superfamily used. Therefore we used only a limited number of strains from these 'foreign' taxa (Pseudomonas, Escherichia, Chromobacterium, etc.) (De Ley et al., 1978; De Smedt et al., 1980; De Smedt \& De Ley, 1977; Gillis \& De Ley, 1980; and this paper).

The parameters of additional and reciprocal DNA/rRNA hybridizations are given in Table 3. The results of the reciprocal experiments are in good agreement with the data of the hybridizations in Table 1. The dendrograms Figs 6 and 7 are constructed from the $T_{m(e)}$ values in Table 1 and from many other data in our laboratory. These data were clustered by the unweighted pair group method (Sokal \& Sneath, 1963). Each vertical branch is from a labelled reference rRNA.

\section{DISCUSSION}

The most valid and useful parameter of a DNA/rRNA hybrid is $T_{m(e)}$ (De Smedt \& De Ley, 1977). Its magnitude is a measure of the thermal stability of the hybrids and, as such, a measure of the base sequence similarities between the rRNA cistrons. An additional parameter is the percentage of RNA binding. This parameter is used to differentiate between taxa with the same $T_{m(e)}$. The $T_{m(e)}$ of the homologous duplex of the four reference strains in this paper is $79{ }^{\circ} \mathrm{C}$ or $79.5^{\circ} \mathrm{C}$. This is very close to the values for Janthinobacterium $\left(78.5^{\circ} \mathrm{C}\right.$; De Ley et al., 1978), Beijerinckia $\left(78^{\circ} \mathrm{C}\right.$; De Smedt et al., 1980) and Zymomonas $\left(78^{\circ} \mathrm{C}\right.$; Gillis \& De Ley, 1980) but is lower than the $T_{m(e)}$ of the duplex of most other reference strains (De Ley et al., 1978; De Smedt et al., 1980; De Smedt \& De Ley, 1977; Gillis \& De Ley, 1980). The variation from $78{ }^{\circ} \mathrm{C}$ to $82.5^{\circ} \mathrm{C}$ in the $T_{m(e)}$ of homologous duplexes may be attributed to mismatching in the duplex due to methylation of some bases and/or to the variation of the $\mathrm{mol} \% \mathrm{G}+\mathrm{C}$ in the rRNA cistrons.

The four rRNA similarity maps (Figs 2, 3, 4 and 5) and the dendrograms (Figs 6 and 7) show that the genus Alteromonas is extremely heterogeneous. It divides into four groups and some species of uncertain taxonomic position. These four groups are (1) Alt. macleodii, (2) a large Alt. haloplanktis group, (3) the Alt. putrefaciens group and (4) the Alt. vaga-Alt. communis group. We shall first discuss briefly the content and the position of each group.

(1) Alteromonas macleodii (Fig. 2)

The type strain ATCC 27126 is on a branch separate from all other Alteromonas species examined here. Unfortunately no further strains of this species were available to us. Alt. macleodii has a $70.5^{\circ} \mathrm{C} T_{m(e)}$ against the Alt. haloplanktis group, a $69.1{ }^{\circ} \mathrm{C} T_{m(e)}$ against the $\mathrm{Alt}$. putrefaciens group, and a $66.5^{\circ} \mathrm{C} T_{m(e)}$ against the Alt. vaga-Alt. communis group.

(2) The Alt. haloplanktis group (Fig. 3)

This group is quite heterogeneous: it extends from $73.5^{\circ} \mathrm{C}$ to $79 \cdot 0^{\circ} \mathrm{C} T_{m(e)}$ and from $0 \cdot 17$ to $0.31 \%$ rRNA binding against labelled rRNA of the type strain of Alt. haloplanktis. It is the 

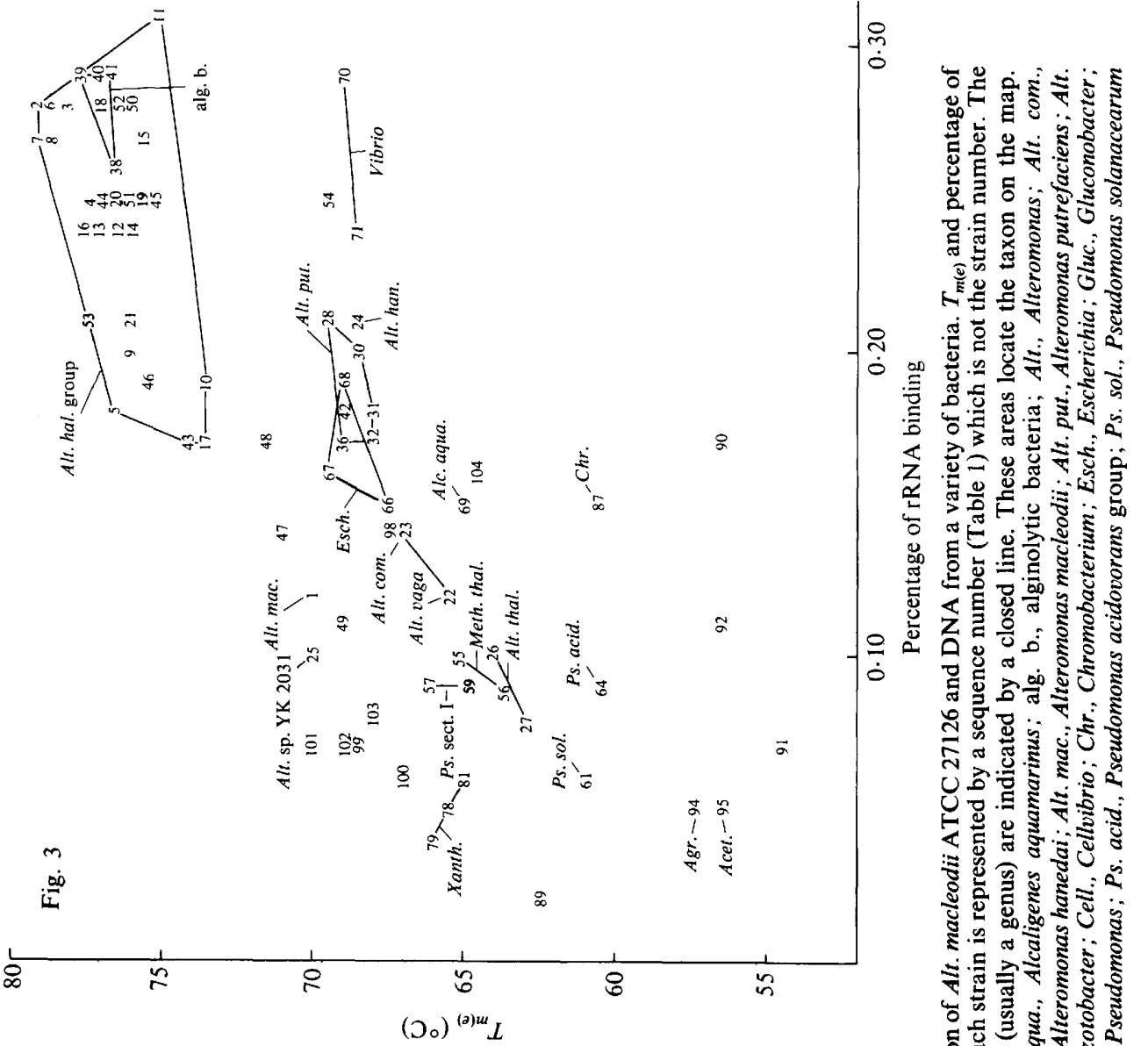

5
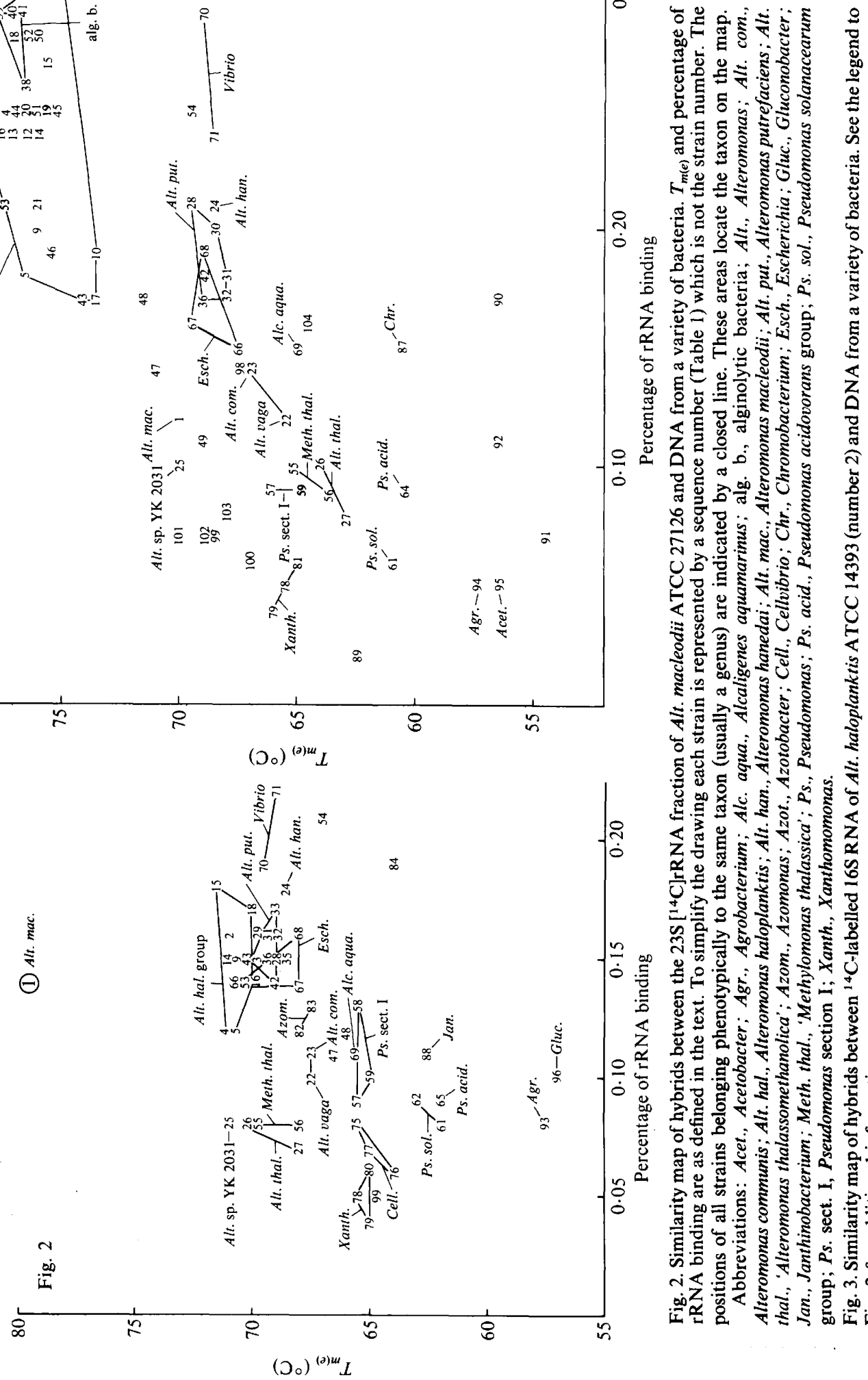

过
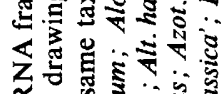

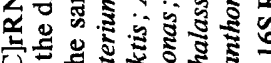

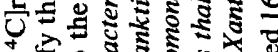

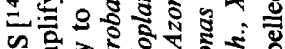

त.

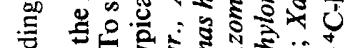

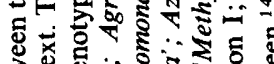

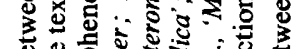

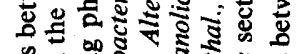

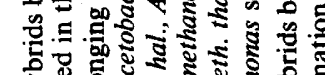

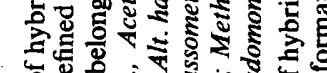
पे 0 \%

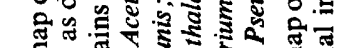

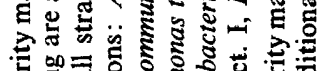
要骂言.气

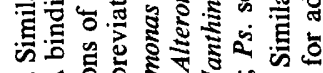

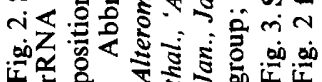




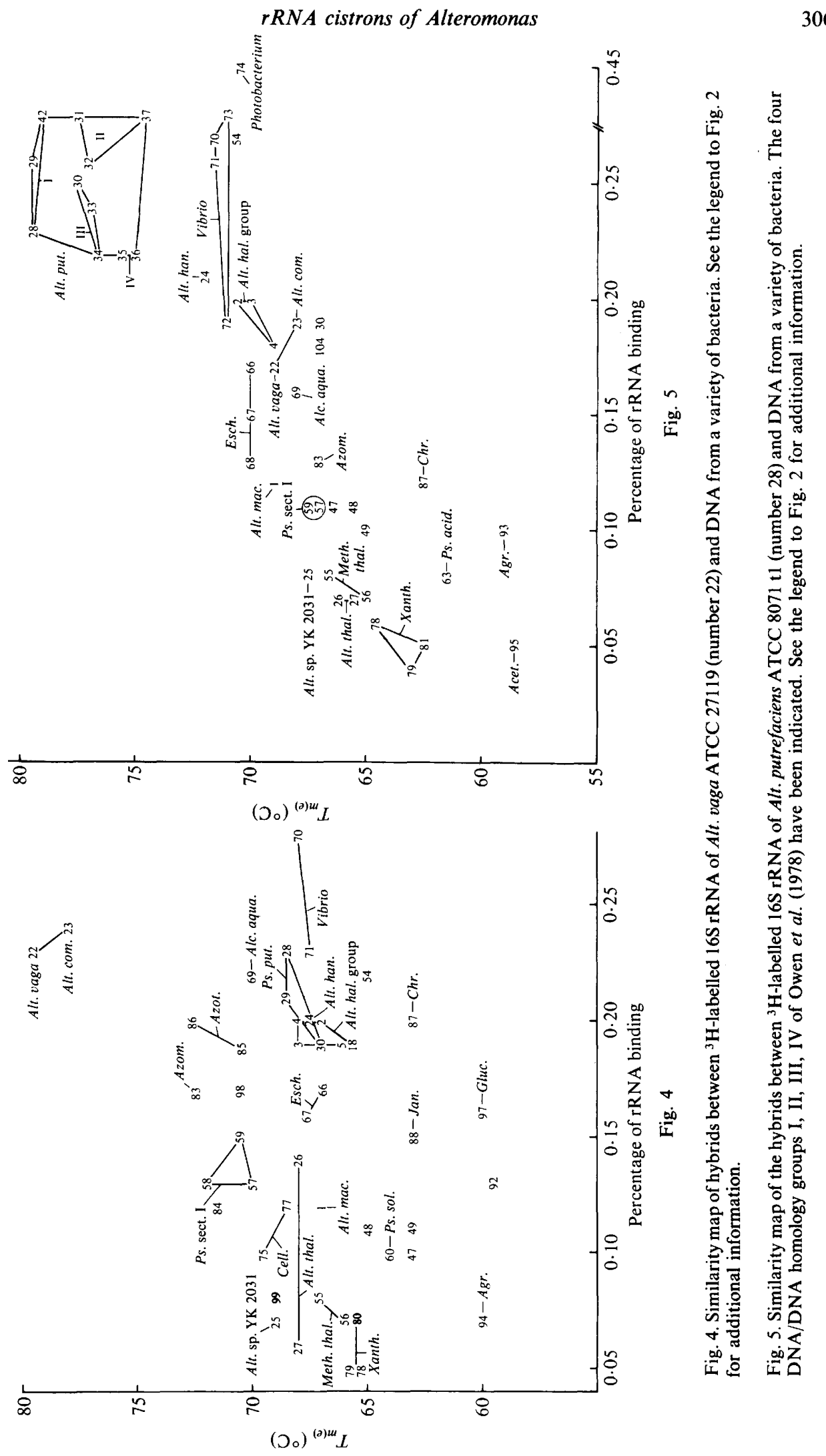




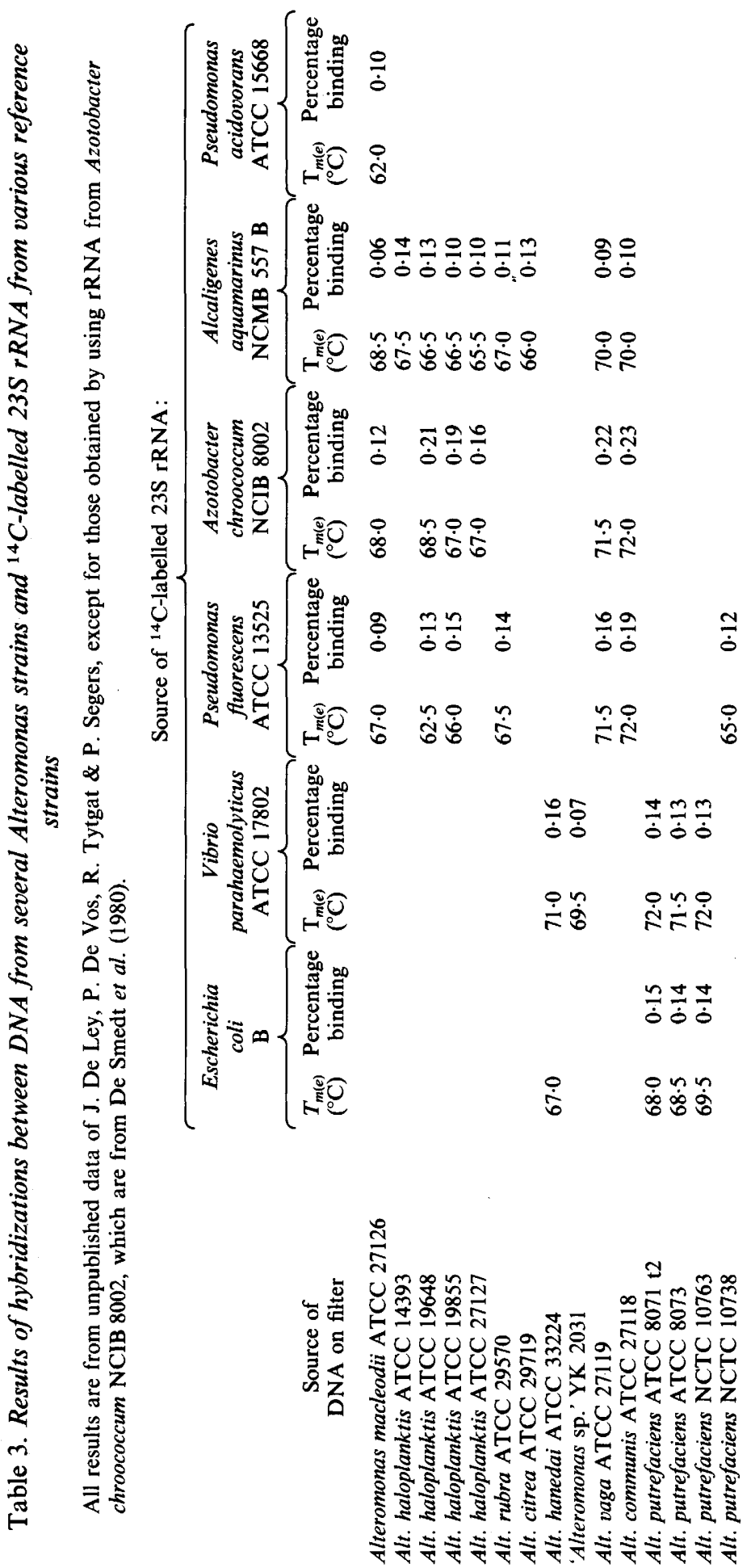




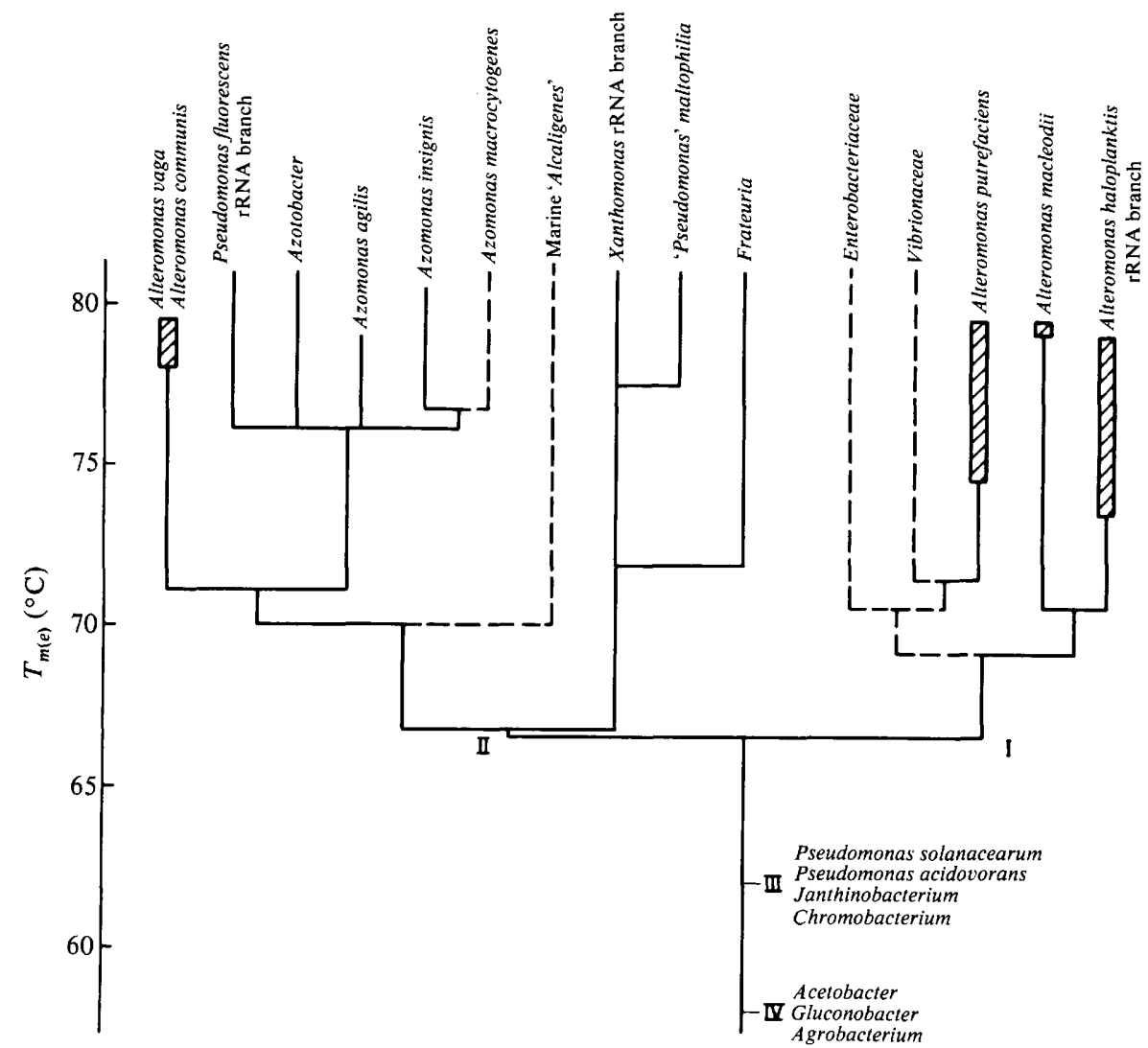

Fig. 6. Position of the four Alteromonas rRNA branches in the first and second rRNA superfamilies. The similarities between the rRNA cistrons are expressed as the $T_{m(e)}$ of their DNA/rRNA hybrids. The general structure of the dendrogram is from published data (continuous lines) and unpublished data (dashed lines) from this laboratory. The extent (heterogeneity) of the four Alteromonas rRNA branches is represented by the hatched bars. The roman numerals indicate the roots of rRNA superfamilies.

largest Alteromonas group. In addition to the reference species, it also contains the following named Alteromonas species: the violacein-producing Alt. luteoviolacea (Gauthier, 1976a, 1982), the prodigiosin-producing Alt. rubra (Gauthier, 1976 b), the lemon-yellow-pigmented Alt. citrea (Gauthier, 1977), the orange-pigmented Alt. aurantia (Gauthier \& Breittmayer, 1979), Alt. espejiana (Chan et al., 1978) and Alt. undina (Chan et al., 1978). Striking phenotypic similarities between these seven species have already been reported (Chan et al., 1978; Gauthier, 1976a, $1976 b, 1977$; Gauthier \& Breittmayer, 1979).

We discovered that a number of misnamed Pseudomonas species and some unnamed alginolytic marine bacteria also belong to this group.

'Pseudomonas atlantica' (Humm, 1946; Yaphe, 1957) ATCC $19262(=$ NCMB 301) and CIP 59.31 (= NCIB 8959), were examined. Both strains are agarolytic. They were isolated from seawater or marine algae in the vicinity of Halifax, Nova Scotia, Canada (Yaphe, 1957). Strain ATCC 19262 is a member of the Alt. haloplanktis group, with a $T_{m(e)}$ of $77.5^{\circ} \mathrm{C}$. Its mol $\% \mathrm{G}+\mathrm{C}$ is 42.3 (our data) or 43.5 (Mandel, 1966). This ' $P$ s. atlantica' strain has been generically misnamed and belongs in the genus Alteromonas. The other ' $P$ s. atlantica' strain is probably quite different from strain ATCC 19262 (see below). Strain CCEB 506 (= CIP 63.28) is not identical with strain ATCC 19262. It was sent many years ago by O. Lysenko as CCEB 506 to the senior author (J.D. L.) and to the Collection de l' Institut Pasteur (CIP 63.28). The mol \% G $+\mathrm{C}$ of the CCEB strain is 66.4 (De Ley \& Friedman, 1965). 


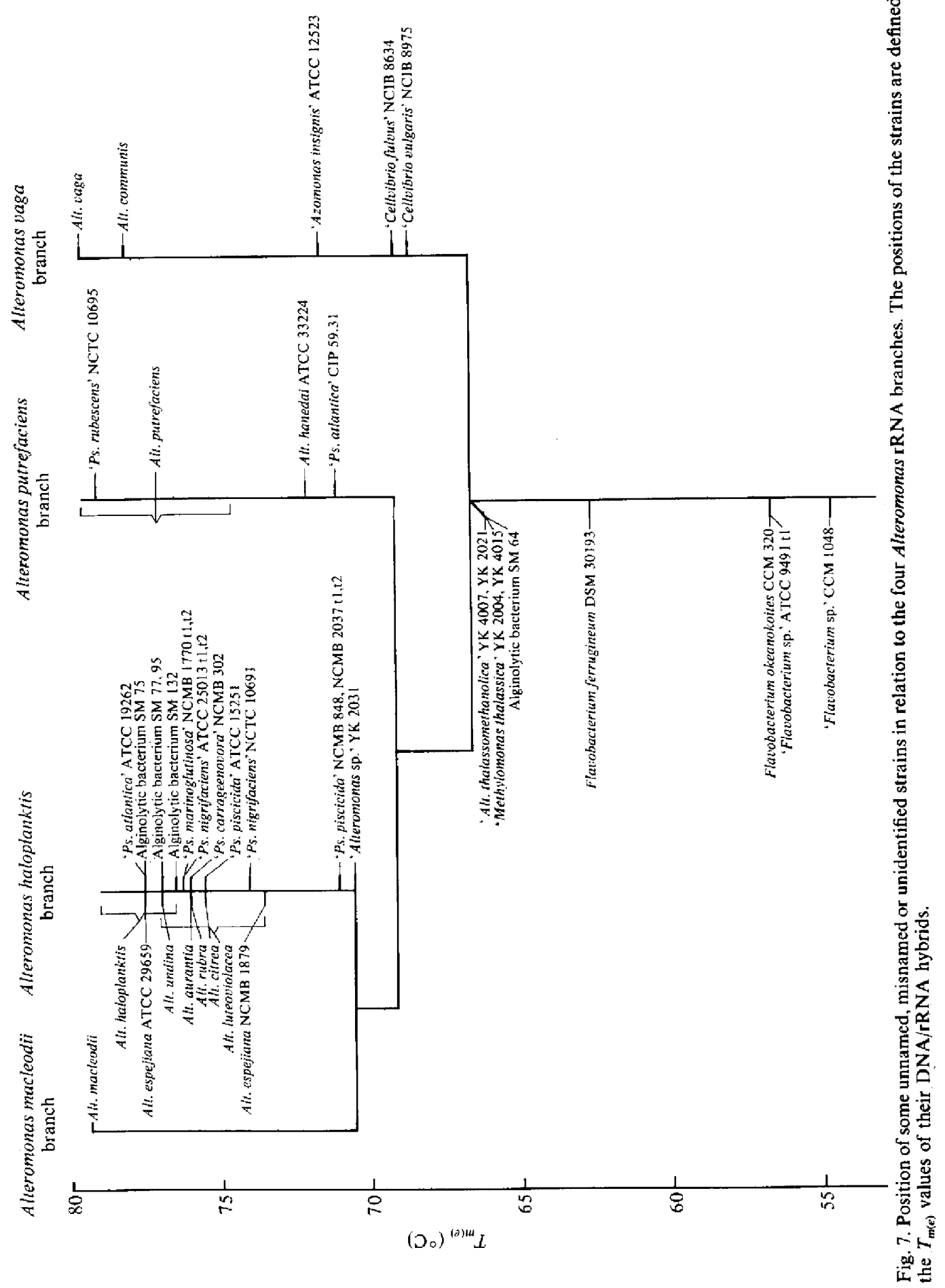


'Pseudomonas marinoglutinosa' (ZoBell \& Allen, 1935; ZoBell \& Upham, 1944) was isolated from slides submerged in the sea for one to seven days at La Jolla, Cal., U.S.A. We used strain NCMB 1770, which displayed two agarolytic colony types: t1 (white) and t2 (beige, transparent). They are probably two variants of the same strain as they fell close together (Fig. 3) with $T_{m(e)}$ values of $76{ }^{\circ} \mathrm{C}$ and $76.5{ }^{\circ} \mathrm{C}$. Their $\mathrm{mol} \% \mathrm{G}+\mathrm{C}$ values are almost the same: $42 \cdot 1$ and 42.2. Strain NCMB 1770 has been misnamed and belongs to the Alt. haloplanktis group.

'Pseudomonas nigrifaciens' was isolated by White (1940) as a Gram-negative, polarly flagellated, strictly aerobic rod from salted butter. It produces a black pigment. Baumann et al. (1972) suspected that strain NCTC 10691 belongs in Alteromonas because of its mol $\% \mathrm{G}+\mathrm{C}$ of 42.9 and its similar phenotypic characters, but they did not make a formal taxonomic assignment. We examined two strains, NCTC 10691 and ATCC 25013 (which consisted of two stable colony types, $\mathrm{t} 1$ and $\mathrm{t} 2$ ). The latter strain was isolated from seawater. Hybridizations show clearly that both strains belong in the Alt. haloplanktis group $\left(T_{m(e)} 74.0\right.$ to $76.5^{\circ} \mathrm{C}$ and $\mathrm{mol} \% \mathrm{G}$ + C 40.4 and 41.0 ) and should thus be renamed.

'Pseudomonas carrageenovora' (Yaphe \& Baxter, 1955) was isolated by these authors from seawater and various marine algae collected in the vicinity of Halifax, Nova Scotia, Canada. The organisms decompose the polysaccharide carrageenin. The species was described, but not named, by Yaphe \& Baxter (1955). The name 'Ps. carrageenovora' was used in later papers (Yaphe, 1959, 1962). We used strain NCMB 302, isolated from red algae, Cow Bay, Nova Scotia, Canada in September 1953. This strain falls clearly in the Alt. haloplanktis group with $76.0{ }^{\circ} \mathrm{C} T_{m(e)}$ and $40.0 \% \mathrm{G}+\mathrm{C}$ and should be renamed as Alteromonas.

'Pseudomonas piscicida' (Bein) Buck, Meyers \& Leifson, 1963 was originally isolated from red tide waters off the south-west coast of Florida, U.S.A. It produces a yellow-orange pigment and is toxic for fish (Bein, 1954). Other strains have since been isolated and studied numerically (Hansen et al., 1965). The mol \% G + C is low (44.5 \pm 1) (Mandel et al., 1966), which excludes it from the genus Pseudomonas. Four strains were examined (strain NCMB 2037 contained two colony types: $\mathrm{t} 1$, beige, and $\mathrm{t} 2$, orange). Their mol $\% \mathrm{G}+\mathrm{C}$ values ranged from 41.9 to 44.5 . Strain ATCC 15251 (an original Bein strain) is located in the Alteromonas area. The three other strains gave $T_{m(e)}$ values a few ${ }^{\circ} \mathrm{C}$ lower (see below).

Of Meland's marine alginolytic strains SM 75, 77, 95, 132 and 64, the first four were isolated from seawater at the surface and at depths of up to $60 \mathrm{~m}$ in the vicinity of Tromsø, northern Norway, between November 1956 and October 1963. Strain 64 was isolated from a floating fragment of Laminaria species in the same general area in September 1955. All strains were isolated by Mrs S. Meland. Strains 75 and 77 were described and named 'Alginovibrio aquatilis', strain 95 was attributed to 'Alginovibrio norvegicus', and strain 64 to 'Alginovibrio immotus' (Meland, 1963). We are not aware of a published description of strain 132; however, the following is known: the cells are small rods, motile with one or two polar flagella; colonies on nutrient agar or fish agar become greyish and later blackish (we did not observe the latter pigment); the organism decomposes agar and alginic acid, and produces acid from carbohydrates (S. Meland, personal communication).

Hybridizations showed that the marine alginolytic strains SM 75, 77, 95 and 132 belong to the Alt. haloplanktis rRNA branch. Strain SM 64 is discussed below.

\section{(3) The Alt. putrefaciens group}

'Pseudomonas' putrefaciens (Derby \& Hammer) Long \& Hammer, 1941 has been briefly reviewed by Bergan (1981). The cells are aerobic Gram-negative rods with one polar flagellum; they produce a typical pinkish, reddish or apricot-coloured water-soluble pigment and $\mathrm{H}_{2} \mathrm{~S}$. The organism has been isolated from clinical sources but also from soil and water, oil brines, etc. 'Pseudomonas' putrefaciens seems to be one of the most important spoilers of protein food kept at chill temperatures $\left(2\right.$ to $4{ }^{\circ} \mathrm{C}$ ). It seems to be rather heterogeneous phenotypically (Debois et al., 1975; Levin, 1972; Riley et al., 1972) and genotypically (43 to $53 \% \mathrm{G}+\mathrm{C}$; four DNA homology groups, Owen et al., 1978). These organisms cannot belong to Pseudomonas because the mol \% G $+\mathrm{C}$ is too low. Lee et al. (1977) proposed on phenotypic grounds to rename this taxon as Alt. putrefaciens. Our DNA/rRNA hybridizations (Table 1; Figs 5 and 7) showed that nine Alt. 
putrefaciens strains, with mol $\% \mathrm{G}+\mathrm{C}$ ranging from $44 \cdot 4$ to $53 \cdot 3$, and from very diverse origins (haddock, cuttlefish, butter, faeces, oil brine, cerebrospinal fluid, bottled blood) all belonged in one rRNA branch separate from all others. Although the resolution of the DNA/rRNA hybridization method is limited within a species or a small genus, we could nevertheless distinguish the four DNA homology groups of Owen et al. (1978). In addition, by plotting the DNA homology data from Owen et al. (1978) against our $T_{m(e)}$ values for the same pairs of strains, it is found that the top 6 or $7^{\circ} \mathrm{C}$ of the $T_{m(e)}$ range corresponds to the entire 0 to $100 \%$ DNA homology scale, a conclusion agreeing very well with previous calculations on Pseudomonas (De Vos \& De Ley, 1983).

'Pseudomonas rubescens' (Pivnick, 1955) was originally isolated from oil emulsions from factories. It is a pink, aerobic, Gram-negative rod with one polar flagellum, producing $\mathrm{H}_{2} \mathrm{~S}$. Pivnick (1955) recognized the close similarity with 'Ps.' putrefaciens. Recently the identity between both species has been repeatedly stressed: phenotypically (Lee et al., 1977), by DNA/ DNA hybridizations (Owen et al., 1978), and by lipid analysis (Wilkinson \& Caudwell, 1980). Our rRNA hybridizations confirm this: 'Ps. rubescens' NCTC 10695, isolated by Pivnick from an oil emulsion from a machine shop, resembles most closely the type strain of Alt. putrefaciens.

\section{(4) The Alt. vaga-Alt. communis group}

Unfortunately, only the type strain of each species was available. They are very similar (Figs 4 and 7) to each other but very different from all other alteromonads (see below). No other organisms tested belonged to the Alt. vaga-Alt. communis rRNA branch: they all remained below $72.5^{\circ} \mathrm{C} T_{m(e)}$.

\section{Relationships among the different Alteromonas rRNA branches and their position among the Gram-negative bacteria}

The genus Alteromonas is extremely heterogeneous. All four rRNA branches are 9 to $13{ }^{\circ} \mathrm{C}$ $\Delta T_{m(e)}$ removed from each other. This is greater than, for example, the differences between Pseudomonas and Azotobacter (De Smedt et al., 1980), between Xanthomonas and Frateuria (Swings et al., 1980) or between Janthinobacterium, Alcaligenes and Bordetella (De Ley et al., 1978; J. De Ley \& P. Segers, unpublished). At least two of these four Alteromonas groups are thus different at and above the genus level.

The Alt. haloplanktis and Alt. macleodii rRNA branches are both members of the first rRNA superfamily sensu De Ley (1978). They are closest to each other, at $9{ }^{\circ} \mathrm{C} \Delta T_{m(e)}$. Some noticeable phenotypic differences might be expected. However, phenotypically Alt. macleodii is not clearly separated from the species of the Alt. haloplanktis group; it differs in 6 out of about 200 features listed: growth on salicin, D-gluconate, DL-glycerate, and glycerol; synthesis of antibiotics and resistance to thiophenicol. Alteromonas espejiana, which belongs to the Alt. haloplanktis rRNA branch, has a slightly greater phenotypic similarity to Alt. macleodii than to Alt. haloplanktis. At present there seem to be no convincing phenotypical arguments to separate the two rRNA branches. The genus Alteromonas can temporarily be delineated above about $70^{\circ} \mathrm{C} T_{m(e)}$ with an atypical Alt. macleodii as type species. In this case one should also admit three more low $T_{m(e)}$ strains to this genus: 'Ps piscicida' NCMB 2037 and NCMB 848, and 'Alteromonas sp.' YK 2031, a facultative methylotroph of marine origin. The genus description by Baumann et al. (1972) should be extended with the features in Table 4.

The Alt. putrefaciens rRNA cluster (including 'Ps. rubescens') is closer to the family of the Vibrionaceae (average $T_{m(e)} 71.4^{\circ} \mathrm{C}$ ) than to the Enterobacteriaceae (average $T_{m(e)} 69 \cdot 3{ }^{\circ} \mathrm{C}$ ) or the Alt. macleodii and Alt. haloplanktis branches (average $T_{m(e)} 68.6{ }^{\circ} \mathrm{C}$ ). Our results suggest that Alt. putrefaciens is not an Alteromonas, but deserves separate genus status. Recently Wilkinson \& Caudwell (1980) found significant differences between the lipids and fatty acids of the putrefaciens organisms and those reported for a strain of Alt. haloplanktis (DiRienzo \& MacLeod, 1978), thus opposing the inclusion of the putrefaciens organisms in the genus Alteromonas. One would expect that there are several other phenotypic differences. Unfortunately the individual strains of Alt. putrefaciens have been incompletely described so far. More phenotypic data on Alt. putrefaciens would be useful. 
Table 4. Features differentiating between the proposed genus Marinomonas and the remaining members of the genus Alteromonas

The data were taken from the literature: a, Baumann et al. (1972); $b$, Chan et al. (1978); $c$, Reichelt \& Baumann (1973); $d$, Gauthier (1976a); $e$, Gauthier (1982); $f$, Gauthier (1976b); g, Gauthier (1977); $h$, Gauthier \& Breittmayer (1979).

The symbols + and - are used to indicate that all strains of the species were positive or negative, respectively, with respect to the property tested. The numbers in the table indicate the number of positive strains. ND, Not determined; $m$, meta cleavage.

\begin{tabular}{|c|c|c|c|c|c|c|c|c|c|c|}
\hline & $M a$ & inomonas & & & & Alter & monas & & & \\
\hline & 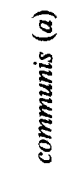 & $\begin{array}{l}\widehat{\sigma} \\
0 \\
8 \\
5 \\
0\end{array}$ & 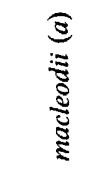 & 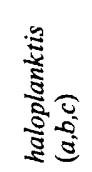 & 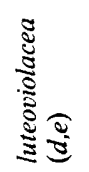 & 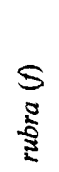 & 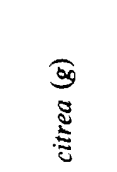 & $\begin{array}{l}\widehat{0} \\
5 \\
5 \\
: \frac{1}{2} \\
\frac{1}{2}\end{array}$ & 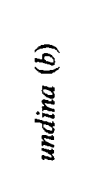 & 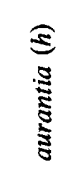 \\
\hline No. of strains & 33 & 17 & 21 & 25 & 16 & 3 & 3 & 18 & 8 & 4 \\
\hline Ring cleavage & $\mathrm{m}$ & $\mathrm{m}$ & - & - & ND & - & - & - & - & - \\
\hline Gelatinase & - & - & 20 & + & + & + & + & + & + & + \\
\hline Lipase & - & - & + & + & + & + & + & + & + & + \\
\hline Saccharate & + & + & - & - & ND & ND & ND & - & - & ND \\
\hline DL-Malate & + & + & - & - & - & - & - & - & - & - \\
\hline 2-Oxoglutarate & + & + & - & - & - & - & - & - & - & - \\
\hline Sorbitol & + & + & - & - & - & - & - & - & - & - \\
\hline meso-Inositol & + & + & - & - & - & - & - & - & - & - \\
\hline$m$-Hydroxybenzoate & + & + & - & - & - & - & - & - & - & - \\
\hline$p$-Hydroxybenzoate & + & + & - & - & - & ND & - & - & - & - \\
\hline Quinate & + & + & - & - & - & ND & ND & - & - & ND \\
\hline D- $\alpha$-Alanine & + & + & - & - & - & ND & - & - & - & - \\
\hline L-Ornithine & + & + & - & 1 & - & - & - & ND & ND & - \\
\hline$\gamma$-Aminobutyrate & + & 16 & - & - & ND & ND & ND & - & - & - \\
\hline Betaine & + & 16 & - & - & ND & ND & ND & ND & ND & - \\
\hline Sarcosine & + & + & - & - & ND & ND & ND & - & - & - \\
\hline Putrescine & + & 15 & - & - & ND & ND & ND & - & - & ND \\
\hline $\mathrm{G}+\mathrm{C}$ range $(\mathrm{mol} \%)$ & $46-48$ & $46 \cdot 5-49$ & $44 \cdot 5-46$ & $42-44$ & $41-42$ & 47 & $41 \cdot 5-44$ & $43-44$ & $43-44$ & $39-42$ \\
\hline
\end{tabular}

The Alt. communis-Alt. vaga branch is quite far away from the three other Alteromonas branches and from the entire first rRNA superfamily, at $66.7^{\circ} \mathrm{C} T_{m(e)}$. The Alt. communis-Alt. vaga rRNA branch is a member of the second rRNA superfamily. It is close to, but still distinctly different from, the Pseudomonas section 1-Azotobacter-Azomonas cluster, at $71.5^{\circ} \mathrm{C}$ $T_{m(e)}$. From our extensive experience with this method (De Ley \& De Smedt, 1975; De Ley et al., 1978; De Smedt et al., 1980; De Smedt \& De Ley, 1977; Gillis \& De Ley, 1980) we conclude that the Alt. vaga-Alt. communis group is certainly not a member of Alteromonas; it constitutes a new genus, which is part of a different family. This is supported by the fact that data in the literature reveal considerable phenotypic differences between the Alt. vaga-Alt. communis rRNA branch on the one hand, and the Alt. macleodii and Alt. haloplanktis branches on the other hand (Table 4). Therefore we propose Marinomonas (L. adj. marinus, pertaining to the sea; Gr. n. monas, a unit, monad; M.L. Marinomonas, sea monad) as a new genus for both species, with M. communis as the type species and ATCC 27118 as the type strain. The description of the new genus is the same as that given for the Alt. communis-Alt. vaga group by Baumann et al. (1972).

\section{Organisms excluded from Alteromonas (Table 1 and Fig. 7)}

Among the Gram-negative organisms which we examined by DNA/rRNA hybridizations, because of their low $\mathrm{mol} \% \mathrm{G}+\mathrm{C}$ and/or their marine origin, the following strains were shown not to belong to Alteromonas.

(a) Strains at the bottom of the Alt. putrefaciens rRNA branch. Marine, luminous rods with one polar flagellum and with a mol $\% \mathrm{G}+\mathrm{C}$ of $45 \cdot 2 \pm 0 \cdot 8$, unable to ferment some sugars, have been named Alt. hanedai (Jensen et al., 1980). The type strain ATCC 33224 has a $72{ }^{\circ} \mathrm{C} T_{m(e)}$ 
value against Alt. putrefaciens and a 67.5 to $68.5^{\circ} \mathrm{C}$ value against the other three reference strains. A numerical analysis of phenotypic properties (Jensen et al., 1980) confirms our conclusion that Alt. hanedai is outside the Alt. macleodii-Alt. haloplanktis groups and very different from the Alt. vaga-Alt. communis cluster. Alt. hanedai is separate from both the putrefaciens rRNA branch and from the Vibrionaceae since the $T_{m(e)}$ values with labelled reference rRNA from both taxa are 71 to $72{ }^{\circ} \mathrm{C}$. Strain 'Ps. atlantica' CIP 59.31 with $45 \cdot 4 \% \mathrm{G}+$ $\mathrm{C}$ (see above) groups at $71^{\circ} \mathrm{C} T_{m(e)}$ against Alt. putrefaciens.

(b) Organisms belonging in the second rRNA superfamily (De Ley, 1978). The following three organisms are at about 68.5 to $71.5^{\circ} \mathrm{C} T_{m(e)}$ against the reference $M$. vaga rRNA, and at an average of $65^{\circ} \mathrm{C} T_{m(e)}$ against the Alteromonas rRNAs. Their exact taxonomic position is being examined. 'Cellvibrio fulvus' and 'Cellvibrio vulgaris' (48.2\% and $51.5 \% \mathrm{G}+\mathrm{C}$, respectively) were originally isolated as cellulose decomposers from forest humus in Germany, and are small vibrios with a single polar flagellum (Stapp \& Bortels, 1934). It has been shown in our laboratory that 'Azomonas insignis' ATCC 12523 has been misnamed (De Smedt et al., 1980). The present hybridizations did not succeed in helping to identify this strain.

(c) Organisms of unknown affiliation. The following organisms did not fall specifically on any of the four rRNA branches, and their exact taxonomic affiliations are unknown: the marine methanol-utilizing rods 'Alteromonas thalassomethanolica' YK 4007 and YK 2021, and 'Methylomonas thalassica' YK 2004 and YK 4015 (Yamamoto et al., 1980); and the alginolytic bacterium SM 64 of Meland (1963).

In a previous study of DNA/rRNA hybridizations in Flavobacterium (Bauwens \& De Ley, 1981, and unpublished), the low mol \% G + C organisms Flavobacterium ferrugineum DSM 30193, Flavobacterium okeanokoites CCM 320, 'Flavobacterium sp.' CCM 1048 and ATCC $9491 \mathrm{t} 1$ were excluded from this genus. From the present results it follows that they are also excluded from Alteromonas and Marinomonas. Their exact taxonomic position remains unknown.

J.D.L. is indebted to the Fonds voor Kollektief Fundamenteel Onderzoek for research and personnel grants. We are indebted to Drs M. J. Gauthier, R. J. Owen, K. Kouno, M. L. Lizarraga-Partida, S. Meland and Miss M. S. Hendrie for the gracious gift of strains. We are particularly indebted to Dr S. Meland for valuable unpublished information.

\section{REFERENCES}

ANONYMOUS (1981). Validation of the publication of new names and new combinations previously effectively published outside the IJSB. International Journal of Systematic Bacteriology 31, 215-218.

Baumann, L., Baumann, P., Mandel, M. \& Allen, R. D. (1972). Taxonomy of aerobic marine eubacteria. Journal of Bacteriology 110, 402-429.

BaUWens, M. \& DE LEY, J. (1981). Improvements in the taxonomy of Flavobacterium by DNA :rRNA hybridizations. In The Flavobacterium-Cytophaga Group, pp. 27-31. Edited by H. Reichenbach \& O. B. Weeks. Weinheim: Verlag Chemie.

BEIN, S. J. (1954). A study of certain chromogenic bacteria isolated from 'Red Tide' water with a description of a new species. Bulletin of Marine Sciences of the Gulf and Caribbean 4, 110-119.

BERgan, T. (1981). Human- and animal-pathogenic members of the genus Pseudomonas. In The Prokaryotes 1, pp. 666-701. Edited by M. P. Starr, H. Stolp, H. G. Trüper, A. Balows \& H. G. Schlegel. New York, Heidelberg \& Berlin: Springer-Verlag.

BuCK, J. D., Meyers, S. P. \& LeIfson, E. (1963). Pseudomonas (Flavobacterium) piscicida Bein comb. nov. Journal of Bacteriology 86, 1125-1126.

BURton, K. (1956). A study of the conditions and mechanism of the diphenylamine reaction for the colorimetric estimation of deoxyribonucleic acid. Biochemical Journal 62, 315-323.

Chan, K. Y., BaumanN, L., Garza, M. M. \& Baumann, P (1978). Two new species of Alteromonas - A. espejiana and A. undina. International Journal of Systematic Bacteriology 28, 217-222.

Debois, J., Degreef, H., VandepitTe, J. \& Spaepen, J. (1975). Pseudomonas putrefaciens as a cause of infection in humans. Journal of Clinical Pathology 28, 993-996.

DE LEY, J. (1967). The quick approximation of DNA base composition from absorbancy ratios. Antonie van Leeuwenhoek 33, 203-208.

DE LEY, J. (1978). Modern molecular methods in bacterial taxonomy: evaluation, application, prospects. Proceedings of the 4th International Conference on Plant Pathogenic Bacteria, Angers, pp. 347-357.

DE LEY, J. \& DE SMEDT, J. (1975). Improvements of the membrane filter method for DNA : rRNA hybridizations. Antonie van Leeuwenhoek 41, 287-307.

De Ley, J. \& Friedman, S. (1965). Similarity of Xanthomonas and Pseudomonas deoxyribonucleic acid. Journal of Bacteriology 89, 1306-1309.

De Ley, J., Segers, P. \& Gillis, M. (1978). Intra- and 
intergeneric similarities of Chromobacterium and Janthinobacterium ribosomal ribonucleic acid cistrons. International Journal of Systematic Bacteriology 28, 154-168.

DE SMedT, J. \& DE LEY, J. (1977). Intra- and intergeneric similarities of Agrobacterium ribosomal ribonucleic acid cistrons. International Journal of Systematic Bacteriology 27, 222-240.

De Smedt, J., Bauwens, M., Tytgat, R. \& De Ley, J. (1980). Intra- and intergeneric similarities of ribosomal ribonucleic acid cistrons of free-living, nitrogenfixing bacteria. International Journal of Systematic Bacteriology 30, 106-122.

De Vos, P. \& DE LEY, J. (1983). The intra- and intergeneric similarities of Pseudomonas and Xanthomonas ribosomal ribonucleic acid cistrons. International Journal of Systematic Bacteriology 33, 487-509.

Dirienzo, J. M. \& MacLeod, R. H. (1978). Composition of the fractions separated by polyacrylamide gel electrophoresis of the lipopolysaccharide of a marine bacterium. Journal of Bacteriology 136, 158167.

GAUTHIER, M. J. (1976a). Morphological, physiological and biochemical characteristics of some violet pigmented bacteria isolated from seawater. Canadian Journal of Microbiology 22, 138-149.

GAUTHIER, M. J. (1976b). Alteromonas rubra sp. nov., a new marine antibiotic-producing bacterium. International Journal of Systematic Bacteriology 26, 459466.

GaUTHIER, M. J. (1977). Alteromonas citrea sp. nov., a new Gram-negative, yellow-pigmented bacterium isolated from seawater. International Journal of Systematic Bacteriology 27, 349-354.

GAUTHIER, M. J. (1982). Validation of the name Alteromonas luteoviolacea International Journal of Systematic Bacteriology 32, 82-86.

GaUthier, M. J. \& BreitTMayer, V. A. (1979). A new antibiotic-producing bacterium from seawater: $\mathrm{Al}$ teromonas aurantia sp. nov. International Journal of Systematic Bacteriology 29, 366-372.

GILLIS, M. \& DE LEY, J. (1980). Intra- and intergeneric similarities of the ribosomal ribonucleic acid cistrons of Acetobacter and Gluconobacter. International Journal of Systematic Bacteriology 30, 7-27.

Hansen, A. J., WeEks, O. B. \& ColWell, R. R. (1965). Taxonomy of Pseudomonas piscicida (Bein) Buck, Meyers \& Leifson. Journal of Bacteriology 89, 752761 .

Humm, H. J. (1946). Marine agar-digesting bacteria of the South Atlantic coast. Duke University Marine Station Bulletin 3, 45-75.

Jensen, M. J., Tebo, B. M., Baumann, P., Mandel, M. \& Nealson, K. H. (1980). Characterization of Alteromonas hanedai, a nonfermentative luminous species of marine origin. Current Microbiology 3, 311-315.

Lee, J. V., Gibson, D. M. \& Shewan, J. M. (1977). A numerical taxonomic study of some Pseudomonaslike marine bacteria. Journal of General Microbiology 98, 439-451.

LEvin, R. E. (1972). Correlation of DNA base composition and metabolism of Pseudomonas putrefaciens isolates from food, human clinical specimens, and other sources. Antonie van Leeuwenhoek 38, 121 127.

LONG, H. F. \& HAMmER, B. W. (1941). Classification of organisms important in dairy products. III. Pseudomonas putrefaciens. Iowa Agricultural Experimental Station Research Bulletin 285, 176-195.

MANDEL, M. (1966). Deoxyribonucleic acid base composition in the genus Pseudomonas. Journal of General Microbiology 43, 273-292.

MANDEl, M., WeEKs, O. B. \& ColWell, R. R. (1966). Deoxyribonucleic acid base composition of Pseudomonas piscicida. Journal of Bacteriology 90, 14921493.

Meland, S. M. (1963). Marine alginate-decomposing bacteria from north Norway. Nytt magasin for botanikk 10, 53-80.

Midgley, J. E. M. (1965). Effects of different extraction procedures on the molecular characteristics of bacterial ribosomal ribonucleic acid. Biochimica et biophysica acta 95, 232-243.

OWen, R. J., Legros, R. M. \& LAPAGe, S. P (1978). Base composition, size and sequence similarities of genome deoxyribonucleic acids from clinical isolates of Pseudomonas putrefaciens. Journal of General Microbiology 104, 127-138.

Pivnick, H. (1955). Pseudomonas rubescens, a new species from soluble oil emulsions. Journal of Bacteriology 70, 1-6.

Reichelt, J. L. \& BaumanN, P. (1973). Change of the name Alteromonas marinopraesens to Alteromonas haloplanktis comb. nov. and assignment of strain ATCC 23821 and strain C-Al of De Voe and Oginski to this species. International Journal of Systematic Bacteriology 23, 438-441.

RICHARDS, G. M. (1974). Modification of the diphenylamine reaction giving increased sensitivity and simplicity in the estimation of DNA. Analytical Biochemistry 57, 369-376.

Riley, P. S., TAtum, H. W. \& Weaver, R. E. (1972). Pseudomonas putrefaciens isolates from clinical specimens. Applied Microbiology 24, 798-800.

Skerman, V. B. D., McGowan, V. \& SNeath, P. H. A. (editors) (1980). Approved lists of bacterial names. International Journal of Systematic Bacteriology 30, $225-420$.

Sokal, R. R. \& SNeath, P. H. A. (1963). Principles of Numerical Taxonomy. London: Freeman.

StaPP, C. \& Bortels, H. (1934). Mikrobiologische Untersuchungen über die Zersetzung von Waldstreu. Zentralblatt für Bakteriologie und Parasitenkunde (Abteilung II) 90, 28-66.

Swings, J., Gillis, M., Kersters, K., De Vos, P., Gossele, F. \& DE LEY, J. (1980). Frateuria, a new genus for 'Acetobacter aurantius'. International Journal of Systematic Bacteriology 30, 547-556.

WEEKS, O. B. (1974). Genus Flavobacterium. In Bergey's Manual of Determinative Bacteriology, 8th edn, pp. 357-364. Edited by R. E. Buchanan \& N. E. Gibbons. Baltimore: Williams \& Wilkins.

White, A. H. (1940). A bacterial discoloration of print butter. Scientific Agriculture 20, 638-645.

Wilkinson, S. G. \& Caudwell, P. F. (1980). Lipid composition and chemotaxonomy of Pseudomonas putrefaciens (Alteromonas putrefaciens). Journal of General Microbiology 118, 329-341. 
Yamamoto, M., Iwaki, H., Kouno, K. \& INUI, T. (1980). Identification of marine methanol-utilizing bacteria. Journal of Fermentation Technology 58, 99106.

YAPHE, W. (1957). The use of agarase from Pseudomonas atlantica in the identification of agar in marine algae (Rhodophyceae). Canadian Journal of Microbiology 3, 987-993.

YAPHE, W. (1959). The determination of K-carrageenin as a factor in the classification of the Rhodophyceae. Canadian Journal of Botany 37, 751757.
YAPHE, W. (1962). Detection of marine alginolytic bacteria. Nature, London 196, 1120-1121.

YAPHE, W. \& BAXTER, B. (1955). The enzymic hydrolysis of carrageenin. Applied Microbiology 3 , 380-384.

ZoBell, C. E. \& Allen, E. C. (1935). The significance of marine bacteria in the fouling of submerged surfaces. Journal of Bacteriology 29, 239-251.

ZoBell, C. E. \& UPhAM, H. C. (1944). A list of marine bacteria including descriptions of sixty new species. Bulletin of the Scripps Institute of Oceanography 5, 239-292. 